\title{
Early B-cell Factor gene association with multiple sclerosis in the
} Spanish population

\author{
Alfonso Martínez ${ }^{1}$, Ana Mas', Virginia de las Heras², Rafael Arroyo², \\ Miguel Fernández-Arquero ${ }^{1}$, Emilio $\mathrm{G}$ de la Concha* and Elena Urcelay ${ }^{1}$
}

\author{
Address: ${ }^{1}$ Department of Clinical Immunology, Hospital Clinico San Carlos, Madrid, Spain and ${ }^{2}$ Department of Neurology, Hospital Clinico San \\ Carlos, Madrid, Spain \\ Email: Alfonso Martínez - alfmdoncel@terra.es; Ana Mas - anamasfontao@hotmail.com; Virginia de las Heras - v_delasheras@yahoo.es; \\ Rafael Arroyo - rafarro@terra.es; Miguel Fernández-Arquero - mfernandeza.hcsc@salud.madrid.org; Emilio G de la \\ Concha* - egomezdela.hcsc@salud.madrid.org; Elena Urcelay - eurcelay@hcsc.es \\ * Corresponding author
}

Published: 28 October 2005

BMC Neurology 2005, 5:19 doi:10.1 186/147|-2377-5-19
Received: 09 August 2005

Accepted: 28 October 2005

This article is available from: http://www.biomedcentral.com/I47I-2377/5/19

(C) 2005 Martínez et al; licensee BioMed Central Ltd.

This is an Open Access article distributed under the terms of the Creative Commons Attribution License (http://creativecommons.org/licenses/by/2.0), which permits unrestricted use, distribution, and reproduction in any medium, provided the original work is properly cited.

\begin{abstract}
Background: The etiology of multiple sclerosis (MS) is at present not fully elucidated, although it is considered to result from the interaction of environmental and genetic susceptibility factors. In this work we aimed at testing the Early B-cell Factor $(E B F I)$ gene as a functional and positional candidate risk factor for this neurological disease. Axonal damage is a hallmark for multiple sclerosis clinical disability and EBF plays an evolutionarily conserved role in the expression of proteins essential for axonal pathfinding. Failure of B-cell differentiation was found in EBF-deficient mice and involvement of B-lymphocytes in MS has been suggested from their presence in cerebrospinal fluid and lesions of patients.
\end{abstract}

Methods: The role of the EBFI gene in multiple sclerosis susceptibility was analyzed by performing a case-control study with 356 multiple sclerosis patients and 540 ethnically matched controls comparing the EBFI polymorphism rs 1368297 and the microsatellite D5S2038.

Results: Significant association of an EBFI-intronic polymorphism ( $r$ / 368297 , A vs. T: $p=0.02$; $O R=1.26$ and $A A$ vs. $[T A+T T]: p=0.02 ; O R=1.39$ ) was discovered. This association was even stronger after stratification for the well-established risk factor of multiple sclerosis in the Major Histocompatibility Complex, DRBI*I50I (AA vs. [TA+TT]: $P=0.005$; OR = I.78). A trend for association in the case-control study of another $E B F I$ marker, the allele 5 of the very informative microsatellite D5S2038, was corroborated by Transmission Disequilibrium Test of 53 trios ( $\mathrm{p}=$ 0.03).

Conclusion: Our data support EBFI gene association with MS pathogenesis in the Spanish white population. Two genetic markers within the EBFI gene have been found associated with this neurological disease, indicative either of their causative role or that of some other polymorphism in linkage disequilibrium with them. 


\section{Background}

Multiple sclerosis (MS) is one of the most common neurological diseases of young adults in Europe and North America [1]. Similarly to other common complex diseases, the interplay of genome and environment as MS susceptibility factors seems to determine the final outcome. Its precise etiology is at present unknown, even though the first genetic association with the MHC was published more than thirty years ago [2]. Genomic screens support the hypothesis that susceptibility to develop MS is determined by multiple genes with small individual contributions. To decipher those combinations of genes resulting in MS is a major goal of research. Association of MS with the HLA-DRB1*1501-DQB1*0602 haplotype has been unambiguously demonstrated [3]. The diversity of the predisposition genes is evident if we consider that the major risk allele HLA-DRB1*1501 is present only in $33 \%$ of our Spanish MS patients. New susceptibility genes are therefore actively sought worldwide. In the past, candidate gene approaches have successfully revealed associations with disease susceptibility, severity or disease course.

MS has been traditionally considered an autoimmune demyelinating disorder of the central nervous system (CNS) due to autoreactive T cells on myelin proteins. However, other cells and processes have also been involved in the MS immune attack. A role for B cells in MS pathogenesis has been suggested from their presence in the cerebrospinal fluid and lesions of MS patients $[4,5]$. Axonal degeneration [6] has been found in early stages of the disease [7]. Axonal loss is a reliable marker of MS clinical disability [8], although the mechanism underlying axonal damage in MS remains elusive $[9,10]$.

B cells derive from a common lymphoid progenitor, itself derived from a multipotent bone marrow progenitor. The development of a B lymphocyte comprises multiple stages with sequential expression of genes participating in immunoglobulin gene rearrangements and signaling. B cell development depends on a number of transcription factors [11] including early B cell factor (EBF), as shown for the dramatic phenotype of EBF-deficient mice [12]. B cell differentiation to plasma cell in secondary lymphoid organs is an exquisitely regulated process requiring EBF inhibition [13] and a full recapitulation of this B cell final differentiation has been recently described in the CSF [14].

EBF [15] belongs to a family of proteins present in the animal kingdom, the Collier/Olf1/EBF proteins, and it is also expressed in neural cells of different origins. EBF plays an evolutionarily conserved role in the expression of proteins essential for axonal pathfinding and neuronal differentiation in both sensory and motor neurons [16]. In addition to the action of the EBF protein in embryonic neural development, it is expressed in the adult nervous system too [17]. Furthermore, EBF binding activates the Herpes Simplex Virus Type I ICPO (Infected Cell Protein 0) gene promoter, important for productive infection and reactivation from latency [18]. This virus has been related to MS $[19,20]$.

All this evidence prompted us to determine whether the $E B F 1$ gene (coding for the first member of this family cloned in humans), located at chromosome $5 \mathrm{q}$ has any role in MS pathogenesis. Unfortunately, no description of functional EBF1 polymorphisms exists in the literature, and therefore two markers were selected based on strictly genetic parameters. The first is the highly polymorphic D5S2038 microsatellite mapping to the EBF1 gene and the second an intronic single nucleotide polymorphism (rs1368297). The present work shows association of these markers with MS in the Spanish cohorts tested. Most probably MS is consequence of the interaction of a limited number of genetic and environmental risk factors in a patient, which may vary from those present in other patients.

\section{Methods \\ Patients and controls}

Three hundred and fifty six consecutively recruited MS patients from a single center and 540 healthy controls, mainly blood donors and staff, were included in a casecontrol study approved by the Hospital Ethical committee. The MS diagnosis was established based on the Poser criteria [21] and most of these patients have been described in previous studies from our group [22].

\section{Genotyping}

D5S2038 microsatellite was amplified with annealing temperature of $56^{\circ} \mathrm{C}$ using the following set of primers:

\section{Forward: 5' FAM-GTT CAA ATC TTG CCT TTG CC-3'}

\section{Reverse: 5'-GCC ATT GCT TTG TTT ATG CA-3'}

Samples were subsequently denatured and run on an ABI Prism 3100 automatic sequencer (Applied Biosystems, Foster City, CA, USA). Each sample included an internal size standard in order to achieve a highly consistent measure and the results were analyzed using the GeneScan software (Applied Biosystems) and the Local Southern method.

The EBF1 polymorphism (rs1368297) was analyzed by TaqMan Assays-on-Demand (C__2085085_10) from Applied Biosystems, following manufacturer suggestions. 
Table I: Allele frequencies of EBFI microsatellite D5S2038 in MS patients and healthy controls.

\begin{tabular}{cccc}
\hline EBFI D5S2038 & Controls $(n=540)$ & MS patients $(n=356)$ & $P$ \\
\hline 1 & 2 & 2 & 0.99 \\
2 & 27 & 15 & 0.58 \\
3 & 55 & 36 & 0.97 \\
4 & 272 & 176 & 0.78 \\
$5^{*}$ & 246 & 183 & 0.08 \\
6 & 119 & 81 & 0.80 \\
7 & 79 & 47 & 0.54 \\
8 & 146 & 94 & 0.83 \\
9 & 8 & 7 & 0.57 \\
10 & 7 & 4 & 1.00 \\
11 & 3 & 0 & 0.28 \\
\hline
\end{tabular}

$*_{p}=0.08 ;$ OR $(95 \% \mathrm{Cl})=1.26(0.96-1.67)$

Both genetic markers conformed to Hardy-Weinberg equilibrium in the control population.

\section{Statistical analysis}

Allele and genotype frequencies in patients and controls were compared by the $\chi^{2}$ test; $\mathrm{p}$ values were considered significant at a level of $<0.05$. Odds ratio (OR) and $p$ values were calculated using a standard computer package (Epi Info v. 6.02, CDC, Atlanta, USA). The power of the study for the SNP analyzed is above $80 \%$ considering a relative risk of 1.4 and the observed allelic frequency of 0.5 at the standard significance level of 0.05 .

\section{Results}

As microsatellites are very polymorphic and informative genetic markers, we decided to select one within the EBF1 gene, D5S2038, and to study its allele distribution in our cohorts. The case-control analysis of this microsatellite in 356 MS patients and 540 healthy controls yielded the results summarized in Table 1 . As shown, the only allele displaying a trend for association was D5S2038*5, while the frequency of the other ten alleles did not change significantly when patients and controls were compared. No differences were observed when different clinical forms were compared (primary progressive vs relapsing-remitting/secondary progressive). Considering these case-control results, we performed a Transmission Disequilibrium Test (TDT) with 53 trios formed by the patients and their progenitors. Distorted transmission of the D5S2038*5 was observed too (Table 2).

We pursued to check another polymorphism within the EBF1 gene in order to provide more evidence in support of the association of the gene with MS. Data corresponding to the allele and genotype frequencies of the intronic SNP rs1368297 are found in Table 3. Allele A was significantly increased in the diseased population and, under a recessive inheritance model, the AA homozygous geno-
Table 2: Transmission Disequilibrium Test (TDT) of EBFI microsatellite D5S2038 in trios (MS patient and progenitors).

\begin{tabular}{cccc}
\hline EBFI D5S2038 & Transmitted & Non transmitted & $P$ \\
\hline 3 & 5 & 9 & 0.91 \\
4 & 23 & 11 & 0.44 \\
5 & 28 & 15 & 0.03 \\
6 & 3 & 8 & 0.96 \\
7 & 3 & 7 & 0.94 \\
8 & 11 & 10 & 0.50 \\
9 & 0 & 2 & 1.00 \\
10 & 1 & 1 & 0.75 \\
\hline
\end{tabular}

type also conferred predisposition to MS. Moreover, the ratio of risk: non-risk homozygous genotypes was significantly higher among multiple sclerosis patients (AA: TT: p $=0.03 ; \mathrm{OR}[95 \% \mathrm{CI}]=1.56[1.03-2.37])$.

The MS cohort was stratified for the well-known MHC susceptibility factor $D R B{ }^{*} 1501$ and the difference between $D R B 1^{*} 1501^{+}$patients and healthy controls was even stronger than in the unconditioned analysis (Table $4)$.

Finally, when simultaneous carriage of both susceptibility alleles, D5S2038*5 and EBF SNP*A, was compared between MS patients and controls an increment was observed within the diseased cohort $(\mathrm{p}=0.03$; OR $[95 \% \mathrm{CI}]=1.38[1.03-1.84])$.

\section{Discussion}

Information from genomic screens proposed the $5 \mathrm{q}$ chromosomal region as linked to MS [23,24]. Additionally, a recent report compared chromosomal regions, quantitative trait loci (QTLs), of MS patients and of EAE animal models and, by analysis of sequence similarities, defined consensus genes potentially conferring susceptibility to MS [25]. Among them, the EBF1 gene in chromosome $5 \mathrm{q} 34$ was cited, providing positional evidence of the role of this gene in MS predisposition.

Moreover, the simultaneous measurement of thousands of genes upregulated by EBF through microarray technology allowed the detection of 3.5 -fold increase in the expression of interleukin 6 (IL-6) and of the microtubule associated protein tau listed among the top twelve most abundant transcripts [26]. IL-6 has been detected in MS brain and its expression elevated in cerebrospinal fluid of patients $[27,28]$. IL- 6 knockout mice showed resistance to induced EAE, too [29]. The physiological function of tau is to bind to and stabilize microtubules [30] and it is involved in regulation of axonal transport [31]. Tau protein concentration has been found repeatedly increased in cerebrospinal fluid of MS patients [32]. Also morphological examination demonstrated accumulation of amor- 
Table 3: Allele and genotype frequencies of the EBFI polymorphism in multiple sclerosis patients and controls.

\begin{tabular}{cccccc}
\hline EBF rs 1368297 & AA & AT & TT & A & T \\
\hline MS patients & 125 & 168 & 58 & 418 & 284 \\
$(\mathrm{n}=35 \mathrm{I})$ & $35.6 \%$ & $47.8 \%$ & $16.5 \%$ & $59.5 \%$ & $40.5 \%$ \\
Controls & 149 & 267 & 108 & 565 & 483 \\
$(\mathrm{n}=524)$ & $28.4 \%$ & $50.9 \%$ & $20.6 \%$ & $53.9 \%$ & $46.1 \%$ \\
\hline
\end{tabular}

AA vs. $(A T+T T): p=0.02 ;$ OR $(95 \% C l)=1.39(1.03-1.88)$.

$A$ vs. $\mathrm{T}: \mathrm{p}=0.02 ; \mathrm{OR}(95 \% \mathrm{Cl})=1.26(\mathrm{I} .03-1.53)$.

phous deposits of abnormally phosphorylated tau in the cell body and axons of neurons within demyelinating plaques in EAE [33]. Axonopathy has been involved recently in early stages of the pathogenesis of another neurological disease, Alzheimer's disease [34]. Aberrant accumulation of proteins may be crucial to the impairment of axonal transport.

Our results evidence association of the EBF1 gene with MS. There are no functional studies of these gene polymorphisms, although it was cloned more than a decade ago. However, several reports showed transcriptional regulatory elements located in intronic regions of different genes [35-38]. In fact, the susceptibility allele of this EBFintronic polymorphism allows the putative binding of an AP-1 transcription factor and this binding site is disrupted in the presence of the $\mathrm{T}$ allele (as predicted by TFSEARCH ver 1.3). Functional studies of EBF1 will aid in clarifying the role of this gene in MS pathogenesis. Nonetheless, the polymorphisms studied in this work act as genetic markers, which could potentially be the etiologic variants or be in linkage disequilibrium with them.

The EBF prototypical regulatory activity in B lymphocyte differentiation alone justifies the functional involvement of the EBF1 gene in an autoimmune disease as MS. Increasing evidence supports the role in MS disease course of IgM antibodies [39] produced by $\mathrm{CD} 5+$ B-lymphocytes, that are elevated in CSF of patients with aggressive forms of MS [40]. These natural IgM antibodies recognize myelin antigens and are strong complement activators [41]. Both, antibodies and complement, have been shown to contribute to MS disability through demyelination and axonal damage [42]. IgG antibodies with hypermutated V regions have been also described [43]. Moreover, EBF1 is a potent modulator of adipogenesis [44] and the IgM bands in cerebrospinal fluid of MS patients were directed against myelin lipids [40].
Table 4: Genotype frequencies of the EBFI polymorphism in HLA-DRBI*I50I positive and negative multiple sclerosis patients.

\begin{tabular}{cccccc}
\hline EBF rs 1368297 & AA & AT & TT & A & T \\
\hline DRBI*I50I+MS patients* & 51 & 53 & 19 & 155 & 91 \\
$(\mathrm{n}=\mid 23)$ & $41.5 \%$ & $43.1 \%$ & $15.4 \%$ & $63 \%$ & $37 \%$ \\
DRBI*I50I-MS patients & 74 & 115 & 39 & 263 & 193 \\
$(\mathrm{n}=228)$ & $32.5 \%$ & $50.4 \%$ & $17.1 \%$ & $57.7 \%$ & $42.3 \%$ \\
Controls & 149 & 267 & 108 & 565 & 483 \\
$(\mathrm{n}=524)$ & $28.4 \%$ & $50.9 \%$ & $20.6 \%$ & $53.9 \%$ & $46.1 \%$
\end{tabular}

$*$ AA vs. $(\mathrm{AT}+\mathrm{TT}): \mathrm{p}=0.005 ;$ OR $(95 \% \mathrm{Cl})=1.78(\mathrm{I} .16-2.73)$

A vs. $\mathrm{T}: \mathrm{p}=0.01 ; \mathrm{OR}(95 \% \mathrm{Cl})=1.46(1.08-1.96)$

\section{Conclusion}

Our data suggest that the EBF1 gene involved in B-cell development, adipogenesis and axonal damage play a causative role in MS. Many mechanistic ties between axonal damage, tau pathology, intrathecal B1 subpopulation responsible for IgM secretion, conventional B cells, and the EBF1 gene role in MS susceptibility could be thought up. Confirmation in an independent cohort would substantiate our hypothesis about the implications of this gene in MS. Further understanding of the MS pathogenesis will help in the selection of therapeutic targets and characterization of the specific susceptibility genetic pattern in an individual will aid in a better diagnosis and ultimately in achievement of a personalized therapy.

\section{List of abbreviations used}

Early B-cell Factor gene (EBF1).

Multiple sclerosis (MS).

Major Histocompatibility Complex (MHC).

Human leukocyte antigen (HLA).

Central nervous system (CNS).

Infected Cell Protein 0 (ICP0).

Transmission Disequilibrium Test (TDT).

Single nucleotide polymorphism (SNP).

Quantitative trait loci (QTLs).

Experimental autoimmune encephalitis (EAE).

Odds ratio (OR). 


\section{Competing interests}

The author(s) declare that they have no competing interests.

\section{Authors' contributions}

AMartínez carried out the genotyping of some samples and participated in the statistical analysis and writing of the manuscript.

AMas carried out the genotyping of most of the patients and a great part of the controls and participated in the statistical analysis.

VdlH made the diagnosis, participated in the recollection of samples and collaborated in the statistical analysis.

RA made the diagnosis, participated in the recollection of samples and collaborated in the statistical analysis.

MFA participated in the coordination of the study and helped to collect the DNA samples and to interpret the data.

EgdlC participated in the design and coordination of the study and critically revised the article.

EU conceived of the study and participated in the statistical analysis and drafted the major part of the manuscript.

All authors have read and approved the final manuscript.

\section{Acknowledgements}

The authors thank Carmen Martínez for her skilful technical assistance. Elena Urcelay is recipient of a Ramón y Cajal contract of the Spanish Government. Alfonso Martínez is recipient of a research contract of the Spanish Health Ministry (CP04/00 I75). Ana Mas is a fellow of the Alfonso Martín Escudero Fundation. The Spanish FIS 04/099I and the Rodriguez-Pascual Fundation supported this work.

\section{References}

I. Noseworthy JH, Lucchinetti C, Rodriguez M, Weinshenker BG: Multiple sclerosis. N Engl J Med 2000, 343(I3):938-952.

2. Jersild C, Svejgaard A, Fog T: HL-A antigens and multiple sclerosis. Lancet 1972, I(7762): | 240-124I.

3. Olerup $O$, Hillert J: HLA class II-associated genetic susceptibility in multiple sclerosis: a critical evaluation. Tissue Antigens 1991, 38(I): I-I5.

4. Owens GP, Kraus H, Burgoon MP, Smith-Jensen T, Devlin ME, Gilden $\mathrm{DH}$ : Restricted use of VH4 germline segments in an acute multiple sclerosis brain. Ann Neurol 1998, 43(2):236-243.

5. Qin Y, Duquette P, Zhang Y, Talbot P, Poole R, Antel J: Clonal expansion and somatic hypermutation of $\mathbf{V}(\mathrm{H})$ genes of $B$ cells from cerebrospinal fluid in multiple sclerosis. J Clin Invest 1998, I 02(5): 1045-1050.

6. Trapp BD, Peterson J, Ransohoff RM, Rudick R, Mork S, Bo L: Axonal transection in the lesions of multiple sclerosis. $N$ Engl J Med 1998, 338(5):278-285.

7. De Stefano N, Narayanan S, Francis GS, Arnaoutelis R, Tartaglia MC, Antel JP, Matthews PM, Arnold DL: Evidence of axonal damage in the early stages of multiple sclerosis and its relevance to disability. Arch Neurol 200I, 58(I):65-70.
8. De Stefano N, Matthews PM, Fu L, Narayanan S, Stanley J, Francis GS, Antel JP, Arnold DL: Axonal damage correlates with disability in patients with relapsing-remitting multiple sclerosis. Results of a longitudinal magnetic resonance spectroscopy study. Brain 1998, I 2 I (Pt 8): | 469-|477.

9. Pitt $D$, Werner $P$, Raine CS: Glutamate excitotoxicity in a model of multiple sclerosis. Nat Med 2000, 6(I):67-70.

10. Lappe-Siefke C, Goebbels S, Gravel M, Nicksch E, Lee J, Braun PE, Griffiths IR, Nave KA: Disruption of CnpI uncouples oligodendroglial functions in axonal support and myelination. Nat Genet 2003, 33(3):366-374.

II. Busslinger M: Transcriptional control of early B cell development. Annu Rev Immunol 2004, 22:55-79.

12. Lin H, Grosschedl R: Failure of B-cell differentiation in mice lacking the transcription factor EBF. Nature 1995, 376(6537):263-267.

13. Lin KI, Tunyaplin C, Calame K: Transcriptional regulatory cascades controlling plasma cell differentiation. Immunol Rev 2003, 194:19-28.

14. Corcione A, Casazza S, Ferretti E, Giunti D, Zappia E, Pistorio A, Gambini C, Mancardi GL, Uccelli A, Pistoia V: Recapitulation of B cell differentiation in the central nervous system of patients with multiple sclerosis. Proc Natl Acad Sci U S A 2004 , I 0 I (30): I I064- I I069.

15. Wang MM, Reed RR: Molecular cloning of the olfactory neuronal transcription factor Olf-I by genetic selection in yeast. Nature 1993, 364(6433): I2I-I 26.

16. Prasad BC, Ye B, Zackhary R, Schrader K, Seydoux G, Reed RR: unc3 , a gene required for axonal guidance in Caenorhabditis elegans, encodes a member of the O/E family of transcription factors. Development 1998, I25(8): | 56|-I568.

17. Kudrycki KE, Buiakova O, Tarozzo G, Grillo M, Walters E, Margolis FL: Effects of mutation of the Olf-I motif on transgene expression in olfactory receptor neurons. J Neurosci Res 1998 , 52(2): I59- I72.

18. Devireddy LR, Jones CJ: Olf-I, a neuron-specific transcription factor, can activate the herpes simplex virus type I-infected cell protein 0 promoter. J Biol Chem 2000, 275(I):77-8I.

19. Baig S, Olsson O, Olsson T, Love A, Jeansson S, Link H: Cells producing antibody to measles and herpes simplex virus in cerebrospinal fluid and blood of patients with multiple sclerosis and controls. Clin Exp Immunol 1989, 78(3):390-395.

20. Ferrante P, Mancuso R, Pagani E, Guerini FR, Calvo MG, Saresella M, Speciale L, Caputo D: Molecular evidences for a role of HSV-I in multiple sclerosis clinical acute attack. I Neurovirol 2000, 6(Suppl 2):SI09-I I4.

21. Poser CM, Paty DW, Scheinberg L, McDonald WI, Davis FA, Ebers GC, Johnson KP, Sibley WA, Silberberg DH, Tourtellotte WW: New diagnostic criteria for multiple sclerosis: guidelines for research protocols. Ann Neurol 1983, I 3(3):227-23I.

22. Martinez Doncel A, Rubio A, Arroyo R, de las Heras V, Martin C, Fernandez-Arquero M, de la Concha EG: Interleukin- I 0 polymorphisms in Spanish multiple sclerosis patients. J Neuroimmunol 2002, I 3 I (I-2): I68-I72.

23. Sawcer S, Ban M, Maranian M, Yeo TW, Compston A, Kirby A, Daly MJ, De Jager PL, Walsh E, Lander ES, et al.: A high-density screen for linkage in multiple sclerosis. Am J Hum Genet 2005, 77(3):454-467.

24. Kenealy SJ, Babron MC, Bradford Y, Schnetz-Boutaud N, Haines JL, Rimmler JB, Schmidt S, Pericak-Vance MA, Barcellos LF, Lincoln RR, et al: A second-generation genomic screen for multiple sclerosis. Am J Hum Genet 2004, 75(6): 1070-1078.

25. Serrano-Fernandez P, Ibrahim SM, Zettl UK, Thiesen HJ, Godde R, Epplen JT, Moller S: Intergenomic consensus in multifactorial inheritance loci: the case of multiple sclerosis. Genes Immun 2004, 5(8):615-620.

26. Mansson R, Tsapogas P, Akerlund M, Lagergren A, Gisler R, Sigvardsson $M$ : Pearson correlation analysis of microarray data allows for the identification of genetic targets for early B-cell factor. J Biol Chem 2004, 279(I 7): I7905-I79|3.

27. Maimone D, Guazzi GC, Annunziata P: IL-6 detection in multiple sclerosis brain. J Neurol Sci 1997, I 46(I):59-65.

28. Navikas $V$, Matusevicius $D$, Soderstrom M, Fredrikson S, Kivisakk $P$, Ljungdahl A, Hojeberg B, Link H: Increased interleukin-6 mRNA expression in blood and cerebrospinal fluid mononuclear cells in multiple sclerosis. J Neuroimmunol 1996, 64(I):63-69. 
29. Okuda Y, Sakoda S, Saeki Y, Kishimoto T, Yanagihara T: Enhancement of Th2 response in IL-6-deficient mice immunized with myelin oligodendrocyte glycoprotein. J Neuroimmunol 2000, 105(2): 120-123.

30. Lee VM, Goedert M, Trojanowski JQ: Neurodegenerative tauopathies. Annu Rev Neurosci 2001, 24: I I2I-II59.

3I. Ebneth A, Godemann R, Stamer K, Illenberger S, Trinczek B, Mandelkow $\mathrm{E}$ : Overexpression of tau protein inhibits kinesindependent trafficking of vesicles, mitochondria, and endoplasmic reticulum: implications for Alzheimer's disease. J Cell Biol 1998, I43(3): 777-794.

32. Kapaki E, Paraskevas GP, Michalopoulou M, Kilidireas K: Increased cerebrospinal fluid tau protein in multiple sclerosis. Eur Neurol 2000, 43(4):228-232.

33. Schneider A, Araujo GW, Trajkovic K, Herrmann MM, Merkler D, Mandelkow EM, Weissert R, Simons M: Hyperphosphorylation and aggregation of tau in experimental autoimmune encephalomyelitis. J Biol Chem 2004, 279(53):55833-55839.

34. Stokin GB, Lillo C, Falzone TL, Brusch RG, Rockenstein E, Mount SL, Raman R, Davies P, Masliah E, Williams DS, et al.: Axonopathy and transport deficits early in the pathogenesis of Alzheimer's disease. Science 2005, 307(57 I3): 1282-I288.

35. Surinya $\mathrm{KH}, \mathrm{Cox}$ TC, May BK: Identification and characterization of a conserved erythroid-specific enhancer located in intron 8 of the human 5 -aminolevulinate synthase 2 gene. J Biol Chem 1998, 273(27):16798-16809.

36. Ghayor C, Herrouin JF, Chadjichristos C, Ala-Kokko L, Takigawa M, Pujol JP, Galera P: Regulation of human COL2AI gene expression in chondrocytes. Identification of C-Krox-responsive elements and modulation by phenotype alteration. J Biol Chem 2000, 275(35):2742I-27438.

37. Ozaki K, Ohnishi Y, lida A, Sekine A, Yamada R, Tsunoda T, Sato H, Hori M, Nakamura Y, Tanaka T: Functional SNPs in the lymphotoxin-alpha gene that are associated with susceptibility to myocardial infarction. Nat Genet 2002, 32(4):650-654.

38. Tokuhiro S, Yamada R, Chang X, Suzuki A, Kochi Y, Sawada T, Suzuki $M$, Nagasaki $M$, Ohtsuki M, Ono $M$, et al:: An intronic SNP in a RUNXI binding site of SLC22A4, encoding an organic cation transporter, is associated with rheumatoid arthritis. Nat Genet 2003, 35(4):34I-348.

39. Villar LM, Masjuan J, Gonzalez-Porque P, Plaza J, Sadaba MC, Roldan $\mathrm{E}$, Bootello A, Alvarez-Cermeno JC: Intrathecal IgM synthesis is a prognostic factor in multiple sclerosis. Ann Neurol 2003, 53(2):222-226.

40. Villar LM, Sadaba MC, Roldan E, Masjuan J, Gonzalez-Porque P, Villarrubia N, Espino M, Garcia-Trujillo JA, Bootello A, Alvarez-Cermeno JC: Intrathecal synthesis of oligoclonal IgM against myelin lipids predicts an aggressive disease course in MS. I Clin Invest 2005, II I (I): 187-194.

41. Sellebjerg F, Christiansen M, Garred P: MBP, anti-MBP and antiPLP antibodies, and intrathecal complement activation in multiple sclerosis. Mult Scler 1998, 4(3): I27-I3I.

42. Mead RJ, Singhrao SK, Neal JW, Lassmann H, Morgan BP: The membrane attack complex of complement causes severe demyelination associated with acute axonal injury. J Immunol 2002, 168(I):458-465.

43. Uccelli A, Aloisi F, Pistoia V: Unveiling the enigma of the CNS as a B-cell fostering environment. Trends Immunol 2005, 26(5):254-259.

44. Akerblad P, Lind U, Liberg D, Bamberg K, Sigvardsson M: Early Bcell factor (O/E-I) is a promoter of adipogenesis and involved in control of genes important for terminal adipocyte differentiation. Mol Cell Biol 2002, 22(22):80I5-8025

\section{Pre-publication history}

The pre-publication history for this paper can be accessed here:

http://www.biomedcentral.com/1471-2377/5/19/prepub

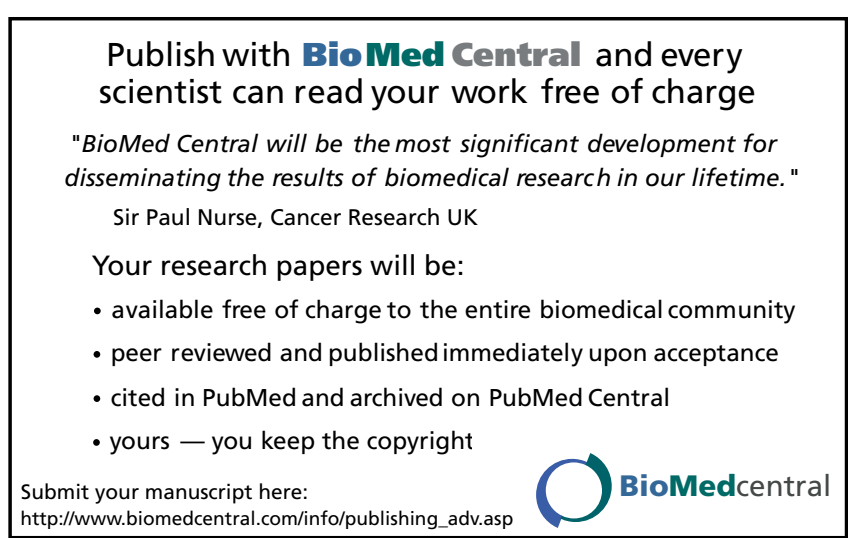

